Volume 6, Issue 4, Ocober 2021, pp. 331-351

DOI: $10.23917 /$ jramathedu.v6i4.15050

p-ISSN: 2503-3697, e-ISSN: 2541-2590

\title{
Ethnomathematics: Modelling the volume of solid of revolution at Buginese and Makassarese traditional foods
}

\author{
Zulfiqar Busrah1 ${ }^{*}$, Hikmawati Pathuddin² \\ ${ }^{1}$ Tadris Matematika, Institut Agama Islam Negeri Parepare, Indonesia \\ ${ }^{2}$ Department of Mathematics, niversitas Islam Negeri Alauddin Makassar, Indonesia \\ Corresponding Author: zulfiqarbusrah@iainpare.ac.id
}

\begin{tabular}{l} 
ARTICLE INFO \\
\hline Article history: \\
Received: 1 July 2021 \\
Revised: 19 September 2021 \\
Accepted: 25 September 2021 \\
Published online: 26 October \\
2021 \\
Published regularly: October \\
2021
\end{tabular}

\footnotetext{
Keywords:

Buginese and Makassarese

traditional food,

ethnomathematics,

interpolation, volume of solid

of revolution
}

ABSTRACT

Ethnomathematics can empirically improve the cognitive abilities of students in elementary and secondary schools. However, in undergraduate study, there are still limited studies on integrating ethnomathematics in learning resources. This study aims to apply interpolation in modelling polynomial functions and integral volume on the shape of Buginese and Makassarese traditional foods. Furthermore, it can be used by students as relevant learning resources regarding interpolation and the concept of volume of solid of revolution (VOSR). This is a qualitative study using an ethnographic approach. The data were collected through observations to obtain general information, interviews with informants to find out food-making techniques, and documentation to obtain physical models of each type of food. Data Analysis Techniques consist of the domain analysis to obtain an overview of Buginese and Makassarese traditional foods and the taxonomic analysis to categorize mathematical concepts obtained from the modeling and simulation. The result of this research reveals that lammang is suitable with the slabs. It can be represented as constant functions that revolved around the $x$-axis or the $y$-axis. While paso, bolu cukke, and cantik manis as well as barongko batara, Putu, and cucuru can be outlined in linear functions rotating about the $x$-axis, $y$-axis, or others fixed-line. They meet the criteria of the disks method. However, they are described in the function of polynomials of $n-$ degree. The use of washers can be described in the model of blundered and sarang semut with a hole in the middle caused by the intersection of two curves rotated about the $x$-axis or the $y$-axis. For shells, the model can be applied to determine the cover volume of the cover of pisang ijo flour and onde-onde. Thus, all types of traditional foods in this study can be appropriate objects for a learning resource in modelling the VOSR.

(C) 2021 Universitas Muhammadiyah Surakarta

\section{Introduction}

The integration of mathematics with various other disciplines encourages someinnovations in mathematics learning. One of the most relevant branches in the development of mathematics learning is Ethnomathematics. Since it was first introduced by D'Ambrosio (1985), ethnomathematic studies have grown rapidly and provided many innovations in mathematics learning. Ethnomathematic brings great benefits such as

To cite this article:

Busrah, Z., \& Pathuddin, H. (2021). Ethnomathematics: Modelling the volume of solid of revolution at Buginese and Makassarese traditional foods. JRAMathEdu (Journal of Research and Advances in Mathematics Education), 6(4), 331-351. https://doi.org/10.23917/jramathedu.v6i4.15050 
maintaining cultural awareness and improving intellectual, social, and emotional intelligence through the uniqueness of the culture owned by students. The approach of local culture-based mathematics learning can change people's perspective regarding the existence of mathematics in daily life (Herawaty, Widada, Novita, Waroka, \& Lubis, 2018).

Ethnomathematic also provides a new approach to the school curriculum. In this case,mathematics learning needs to involve various attributes or cultural activities related to the live of students. Under a cultural approach, ethnomathematic tends to build a strong relationship between students' knowledge and experience related to formal math learning activities (Ezeife, 2002). Moreover, ethnomathematics studies can improve students' understanding in terms ofmathematical concepts through the elaboration of meaning on cultural aspects depthly (Rosa \& Orey, 2011). In this part, the cultural context relates to personal, occupational, and cultural activities.

Ethnomathematics is terminologically divided in three phrases: ethno, mathema and tics. D'Ambrosio (1990) stated that Ethno is defined as a term referred to the socio-cultural context, including language, signs, myths, jargons or motto, stories, symbols and the way of thinking (Orey \& Rosa, 2007). Furthermore, mathema has the meaning of explanation, knowledge, thought, understanding and assessment of phenomena. The suffix of tics denotes the same meaning as techne which means a way. Rosa and Orey (2011) stated that tics or techne is a technique more specifically related to counting, sorting, measuring, classifying, inferring, and modelling.

The study related to ethnomathematics has been widely analyzed and spanned some aspects of culture. The exploration of ethnomathematics at traditional food markets in the Special Region of Yogyakarta has been conducted by the previous study (Huda, 2018). In the study, various mathematical elements, such as types of plane and space geometry, were explored in the shape of traditional snacks. Another exploration has also been found in traditional Buginese foods demonstrating that some kinds of them can be applied as contextual learning resources for students at elementary and secondary school levels (Pathuddin et al., 2021).

Prior studies have uncovered that mathematical concepts are based on local attributes and can be used as a source of learning in elementary and secondary schools (Herawaty et al., 2018; Nur, Waluya, Rochmad, \& Wardono, 2020; Pathuddin, Kamariah, \& Nawawi, 2021). The implementation of ethnomathematics-based contextual learning can improve students' cognitive levels (Nur et al., 2020). However, ethnomathematical studies are less found in a source of learning for students at higher education level. The implementation of ethnomathematics in mathematics learning at the higher education level requires a specific exploration suitable with the topic in courses with local cultural atributes. The study of the introduction of shapes and concepts of 3D shapes in local cultural objects is no longer sufficient as a source of mathematics studies in universities. As courses in calculus and numerical methods, the study of functions, interpolations and integration requires the selection of local cultural objects and relevant substances. Moreover, it could be appropriate learning media for students.

Interpolation is one of specific topics in courses of numerical methods. It refers to a technique used to construct a new function as a mathematic model from a set of pairs $(\mathrm{x}, \mathrm{y})$. In some references, interpolation is presented in an abstract concept and simulated on natural phenomena using numerical computations. Learning resources about interpolation based on local cultural approaches are less explored. Therefore, this study seeks to utilize interpolation techniques in a function showing elements of local culture. Technically, interpolation learning is still presented directly in data pairs $(x, y)$, without being complemented by contexts represented in real data. In addition, the existence of functions 
as a result of interpolation is still abstract (Cheney \& Kincaid, 2012), with the result that it becomes an obstacle in mathematics learning for students.

One of topics in Calculus courses is application of integration (Bittinger, Ellenbogen, \& Surgent, 2012). It is enough hard for students when the contexts presented are different

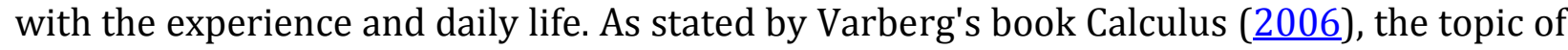
the volume of solid objects is still abstract. The presentation of theory and problem in the context of applications of the integral is only in the form of equations without completing it with a real physical model. Abstract curve is generated directly from a defined function. Although this source presents physical phenomena such as fluid mechanics, moment and center of mass, the phenomena are still far away from the student environment.

Another difficulty encountered in learning the VOSR is the ability to draw graphs, and construct them into rotating objects (Kusumaningrum, Irfan, \& Agustito, 2019; Mofolombokane, Engelbrecht, \& Harding, 2013). Therefore, this research seeks to explore mathematical concepts at the university level by including elements of traditional foods as a part of local culture. Various types of traditional foods are assumed similar to solid of revolution characters, such as cylinders, cones, wheels, and spheres (Huda, 2018; Pathuddin \& Raehana, 2019). The diversity of shapes of traditional food allows them can be represented in various types of polynomials. Moreover, it can be simulated into a solid of revolution.In this study, Buginese and Makassarese traditional foods would be used as the primary object in modeling the VOSR.

In constructing a mathematical model, there are general steps to consider, namely recognizing problems in the surrounding environment or the real world, collecting data, analyzing data, constructing the model, solving the original problem, interpreting the solution, and testing the model. If it has been successful, it will be used to explain, to predict or to decide (Bittinger et al., 2012; Hall \& Lingefjard, 2017). A function representing the phenomenon or real object is the type of mathematical model obtained using interpolation techniques. Such as Newton's polynomial interpolation, it is applied to estimate the data set of a bottle into one polynomial function (Sihombing, Marmaini, \& Dahlia, 2020). However, through the development of numerical computations, interpolation methods have directly been used by software such as (Cooper, 2017). In this study, Interpolation is used as a technique to formulate the polynomial models that could represent the shape of traditional foods.

Furthermore, related to the aspect of using the concept of interpolation and integral in exploring VOSR, it has also been researched by Ozdemir and Cataloglu (2014). This research differs with prior studies. It is in differences between object and focus of the research. In the prior study, Ozdemir and Cataloglu (2014) utilized glass and bottle objects as media for rotating objects. As a distinction, this research further selects traditional Buginese and Makassarese foods. The main focus in Ozdemir's research is to use interpolation studies and integral calculus as a medium in implementing inquiry-based learning (Ozdemir \& Cataloglu, 2014) while this research prioritizes ethnomathematical exploration in the study of integral application to determine the VOSR model.

In addition, the polynomial model through interpolation of each Buginese and Makassarese is visualized into a solid object using the concept of VOSR. From these results, volume models were constructed by the integral application in Calculus. Each model of the volume is categorized in the characteristics of the solid and they are grouped over slabs, disks, washers, and shells (Varberg, Purcell, \& Rigdon, 2006). The process of interpolation, simulation and physical visualization of solid objects is explored using GeoGebra software.

GeoGebra is a mathematical software made firstly by Markus Hohenwarter in 2001 at the University of Salzburg (Hohenwarter \& Hohenwarter, 2002). It has been a multi- 
platform, open source project, and free for educational purpose.The design of the application integrates algebra, plane geometry, 3D geometry functions, statistics and symbolic algebra (Hohenwarter \& Fuchs, 2004). Moreover, GeoGebra can be demonstrating, visualizing and constructing mathematical concepts (Hall \& Lingefjard, 2017). Furthermore, GeoGebra can be used as a learning medium so as to encourage discovery and experimentation both in learning and in exploration activities. Through the use of GeoGebra, students can determine the volume of rotating objects and visualize them independently. Besides, students can also understand how to describe the basic concept of volume of swivel solid disc method (Tasman, Padang, \& Ahmad, 2018). GeoGebra in this study is used as a tool for modeling polynomial representations and fitting curve based on the physical shape of traditional cakes through interpolation techniques. Moreover, GeoGebra is also used to display a simulation of the rotation of the curve about a fixed line.

The main purpose of this research is to apply the concept of interpolation in modelling the VOSR Buginese and Makassarese traditional foods. From a cultural perspective, this study attempts to reveal information about ingredients and techniques in making food and explain the factors affecting the shape of the Buginese and Makassarese foods. This research contributes to the contextual learning resources for mathematics students in higher education. Due to traditional Buginese-Makassarese foods as the object of this research, the contribution also is addressed as the relevant study material for students that knowing Buginese or Makassarese cultural culiners.

\section{Research Methods}

This research is a qualitative using an ethnographic approach. This research identified and explored mathematical models contained in the physical shapes of Buginese and Makassarese traditional foods. The data collection consisted of observation, interview, and documentation. Observation is intended as a step to obtain an initial and general description about traditional foods of Buginese and Makassarese. Furthermore, the interview technique was aimed at obtaining information about recipes, and uses in the cultural perspective of each traditional food. While the documentation is focused on taking pictures that will be processed in modelling and simulation.

Procedurally, this research implemented the ethnographic cycle initiated by Spradley (2006) as cited in Abdullah (2017). The stages included selection of research scope, determining informants, making notes through interviews and documentation, conducting domain analysis, taxonomic analysis and writing ethnographic (Abdullah, 2017; Pathuddin \& Raehana, 2019).

The first stage is the selection of the research scope. In this phase, the types of traditional food are selected and determined spread over several areas whose population is dominated by Buginese and Makassarese ethnics. In this study, the research locations were selected in several cities, including Parepare City, Makassar City, Gowa Regency, Bulukumba Regency, and Barru Regency. Objects were chosen by considering the existence of traditional food sources deriving of some regions in South Sulawesi. In each region, informants were selected based on their involvement in making food, processing food, selling food, or the use of food in cultural activity. In order to ensure the validity of data, a triangulation was implemented. Specifically, data of each type of traditional food in this study require validations from different informants consists of key informants and supporting informants. However, in this study the exact number of informants was not determined. It is based on suitability and sufficiency of information for each type of cake.

Interview is the second stage carried out by asking questions related to the general description of the traditional food being studied. At this stage, structural questions are also 
asked and used to find out information about ingredients, food-making techniques and cultural uses. The third phase is to make ethnographic notes based on the result of interviews and to take photos of traditional food as field notes and documentation. The fourth stage is a domain analysis oriented to an in-depth study of the general description of the traditional food being studied.

The fifth stage is a taxonomic analysis focusing on extracting mathematical concepts by reduction, modelling, and simulation. At this stage, data reduction was carried out by selecting food images from the documentation that meet the criteria for solid of revolutions. Image of each fixed food, selected and imported into GeoGebra. Moreover, at this stage polynomial modeling and fitting curve were also carried out using the interpolation technique. In this part, GeoGebra is used as the main tool in polynomial modeling with interpolation techniques. Expressions of mathematical formulas in GeoGebra can be written in the input box. Especially in interpolation problems, there are several models on the function that can be generated from a data set, namely FitPoly for polynomial functions, FitExp for exponential functions, FitLogistic for logistic models (Hall \& Lingefjard, 2017). However, in this study the GeoGebra command for interpolation only uses Fitpoly to generate polynomial and to fit curve based on the shape of traditional foods. The results of modeling curves with interpolation techniques are grouped based on the degree of polynomial.

In the solid of rotation simulation, it only uses the surface as a command to rotate the curve about the axis. It displays a shape that matches the traditional food observed. The volume model for each type of food is formulated with an integral approach determined based on the slab, disk, washer, and shell method (Bittinger et al., 2012; Varberg et al., 2006). The general description of all stages in this research is illustrated in diagram as follows:

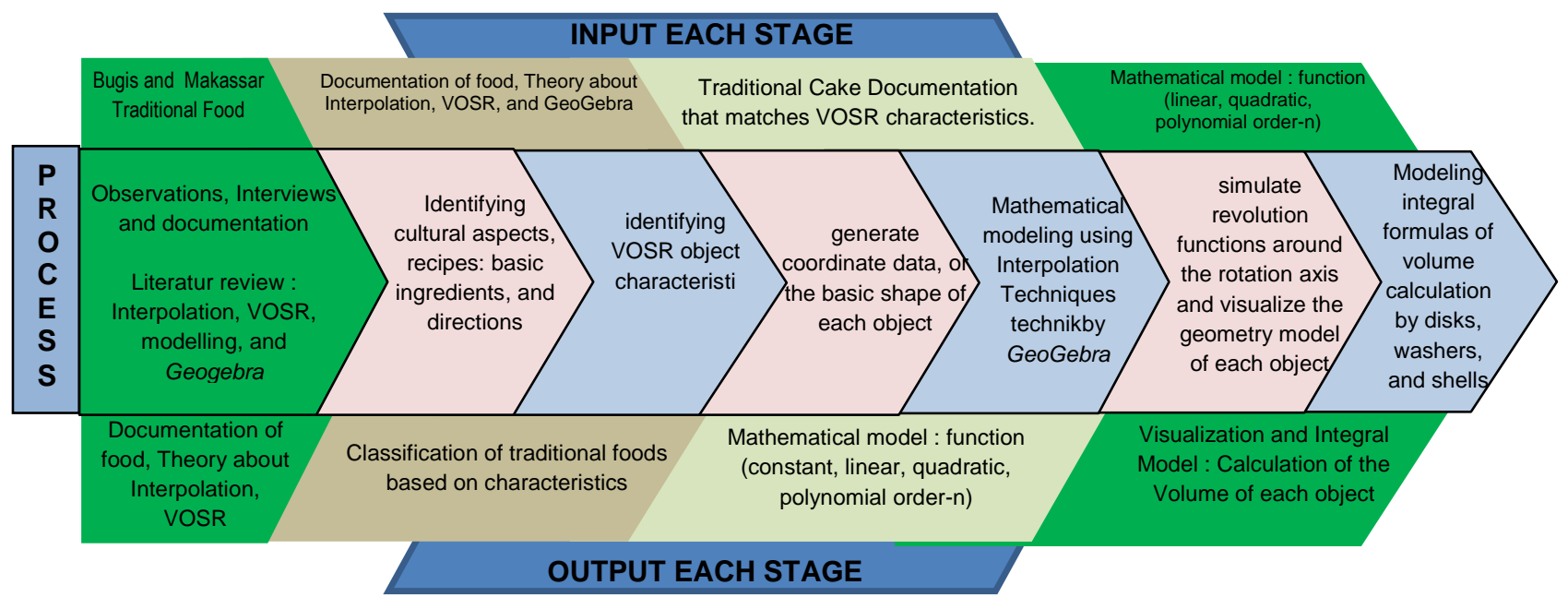

Figure 1. Research stage diagram

The systematic of discussion is presented based on results of classifying the characteristics of the VOSR model and the type of polynomial that is owned by each selected food. The ethnographic notes are added as part of results of interviews regarding ingredients, food-making techniques and cultural aspect of each traditional foods.

\section{Results and Discussion}

Buginese and Makassarese traditional foods can be categorized in the type of staple food, snack food, or food served in the cultural rituals. Based on the observations, there are 
many types of Buginese and Makassarese traditional food, such as lammang, legese, tumbu', kapurung, barobbo', burasa, kampalo, gogos, dumpi cucuru, onde-onde, onde-onde jawa, buroncong, rokok-rokok, pisang ijo, putu cangkir, kue cantik manis, tenteng, baje', barongko, lapisi, katiri salla, pawa', panada, jalang kote', apang, bolu cukke, baruasa, bagea, pallu butung, paranggi, paso. However, not all of the above types of food are compatible with the criteria for solid of revolution. some types of traditional foods suitable with the criteria of solid of revolution are lammang, legese, tumbu', paso, bolu cukke, cantik manis, putu cangkir, cucuru, bludere, sarang semut, pisang ijo, dan onde-onde.

Some prior studies analyze ethnomathematics. Pathuddin and Raehana (2019) have identified the content of the concept of plane figure and geometry on Buginese traditional foods; paso represents the concept of conical, onde-onde denotes the concept of spherical, and putu coppa resembles the concept of a cylinder (Pathuddin \& Raehana, 2019). Huda's research $(\underline{2018})$ has also explored various shapes of traditional market snacks in Yogyakarta. The additional finding is also provided by Pathuddin et al. (2021) focusing on the basic concepts of flat and space figures in the process of making barongko. Their result found that the process of making barongko cakes generates divisions, congruences, and similarities concept (Pathuddin et al., 2021).

The similarities between this study and the research conducted by Huda (2018) and Pathuddin and Raehana ( $\underline{2019}$ ) are the use of traditional food objects. However, this study also has many fundamental differences with previous studies. This research does not emphasize on exploring the suitability of the geometric shapes of traditional foods with the concept of plane and solid figures, but it is more oriented towards a modeling through the interpolation process and the application of integration in modeling the volume of solid of revolution (VOSR). Particularly, the type of solid revolution is reclassified in three methods, namely disks, washers and shells (Varberg et al., 2006). All various foods have been selected based on four characteristics.

\section{Volume of solid: Method of slab}

\section{Lammang}

Lammang is one of traditional foods similar to snacks. It can be found in Buginese and Makassarese community in South Sulawesi. Lammang in many other areas is known as lemang and commonly called as Rice Bamboo (Wahyudi, Octavia, Hadipraja, Isnaeniah, \& Viriani, 2017). Based on the result of interviews with three informants regarding the basic ingredients and the way of making lammang, they explained that:

\footnotetext{
"In the process of making it, lammang needs glutinous rice, coconut milk, and salt as the basic ingredients. In addition, frozen fresh banana leaves and bamboo pieces (bodak) that have a tube-like shape with a length of 40-70 cm and a diameter of 7-15 cm are also required. At the beginning, glutinous rice is washed and rinsed until it is clean. Coconut, milk and salt are used as a seasoning. Glutinous rice and coconut milk mixture with salt are merged into hollow bamboo pieces that is coated young banana leaves. To make it ripe, the bamboo which contains a mixture of rice and spices is burned until desired level of maturity".
}

The basic ingredients and manufacturing techniques presented by informants are similar to manufactures of lemmang in Sumatera (Wahyudi et al., 2017). Based on the result of the interview, it has also been given that in fact there are other types of traditional foods with same characteristics as lammang including legese', tumbu' and lannga'. 


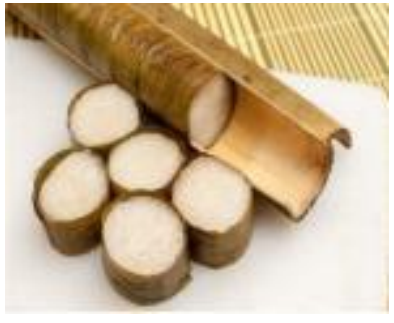

Figure2. Taking lammang in bamboo

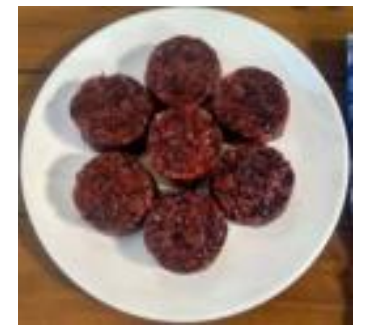

Figure3. Tumbu'

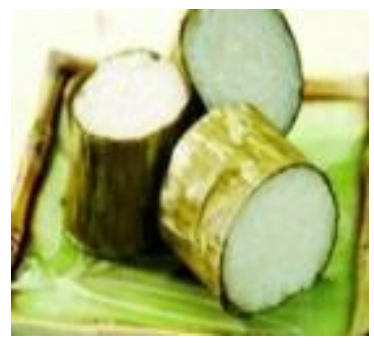

Figure 4. Legesse'

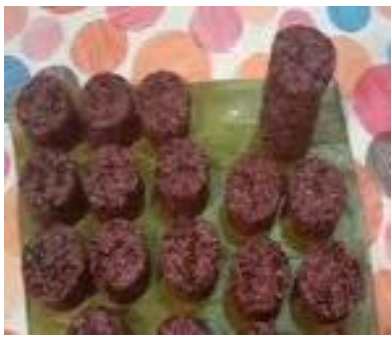

Figure 5. Lannga'

In the mathematical perspective, lammang has the basic circumstance of a solid cylinder because it follows the shape of bamboo as a mold container. Then the young banana leaves as a cover, have become very thin and stick to the edges of glutinous rice matured. Lammang volume can be described practically using formula of volume of a cylinder i.e. $V=\pi r^{2} t$. But in this study, the mathematical model of lammang volume was obtained using applications of integrations. By observing the wide uniformity on the lammang side, the volume model with slabs can be written in a formula as follows:

$$
\Delta V_{\text {lammang }}=A\left(\bar{x}_{i}\right) \Delta x
$$

In this case, the representation of lammang volume with the slab approach can be written in a formula as follows:

$$
V_{\text {lammang }}=\lim _{\Delta x \rightarrow 0} \sum_{i=1}^{n} A\left(\bar{x}_{i}\right) \Delta x=\int_{a}^{b} A(x) d x
$$

While based on the principle of revolution of the object, we need to determine the function representing the outside edge of the lammang. Using the straight edge of the lammang, a function can be yielded by interpolation at just two data points. Through linear interpolation, a constant function is obtained, $g(x)=k$.

This function is rotated around the $x$-axis. In the integral application, if a constant function is revolved around the $x$-axis, then the volume of the rotating object can be determined using the integral. The straight-line, as geometrical representations of constant functions, can be seen as the radius of the lammang equivalent to the value of the constant function (k).

Furthermore, the physical model of lammang can be visualized as follows.

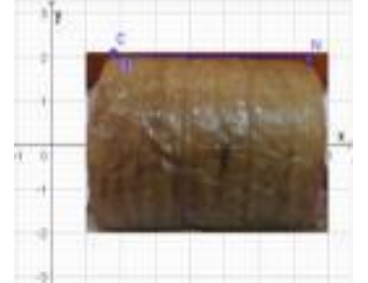

Figure6. Ploting and interpolationof lammang

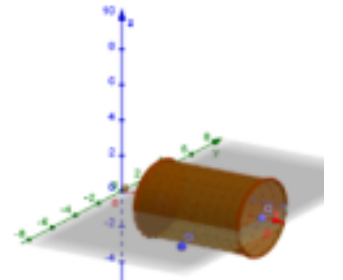

Figure7. Revolution of constant function

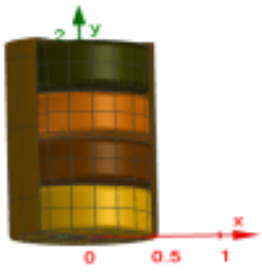

Figure 8. Simulation of revolution of $x=g(y)$ around y-axis

The mathematical model of lammang volume can be represented by:

$$
V_{\text {lammang }}=\pi \int_{a}^{b} k^{2} d x
$$

The principles of model construction and simulation of computational geometry from lammang also apply equally to the types of food tumbu', Lannga' and Legese. Based on the sliced serving method, this type of food is very suitable with a contextual resource in VOSR learning. 
Volume of solid of revolution by disk method

Paso

Paso is one of traditional cakes from Mandar Tribe. However, it can also be consumed by Buginese people. This cake is made from starch, salt to taste, coconut milk, and palm sugar. The ingredients are mixed and stirred until they become liquid doughs. The mixture is put into a cone-shaped banana leaf. According to Pathuddin and Raehana (2019), the characteristics of cones can be found in paso. In this study, paso is explored by constructing the algebraic model using the interpolation method. In addition, the algebraic model is revolutionized around a certain axis of rotation.

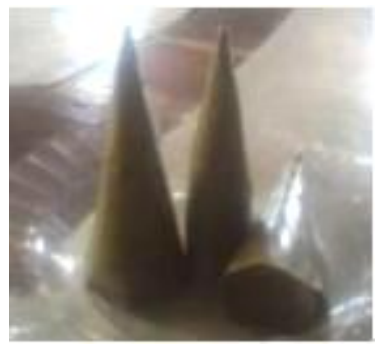

Figure 9. Paso

By using the interpolation, the edge of one piece of paso can be represented in a linear function. In the coordinate system, the peak point of the Pasois centered on $O(0,0)$, then the equation model is obtained $f_{\text {paso }}(x)=m x$. Furthermore, the linear function is rotated around the rotary axis, obtained cones resembling paso. The volume model uses the concept of a rotating solid object disc method. This can be outlined in integral as follows.

$$
V_{\text {paso }}=\pi \int_{a}^{b}(m x)^{2} d x
$$

The geometric visualization of paso can be expanded by considering the direction of rotation not only through the $x$-axis or $y$-axis, but it also simulates the rotation of various linear functions with a varying gradient. The following results showing $r$ simulation of the rotation of linear functions against different types of rotary axes are:

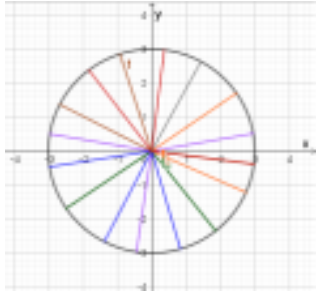

Figure10. Visualization of a set of straight line segments of a paso cake.

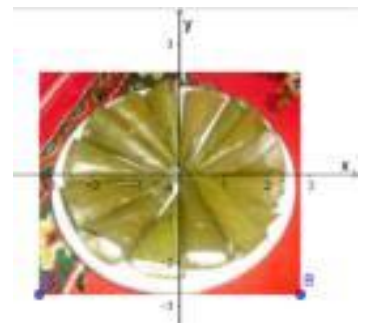

Figure 11. Paso cake serving

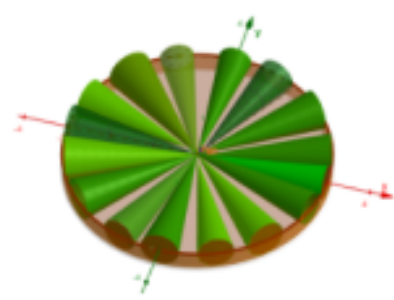

Figure 12. Simulation of revolution of linear equation equals paso cake dish

\section{Bolu cukke and cantik manis}

Another traditional snack in the Buginese-Makassarese community is bolu cukke. This cake can be found in Pinrang, Soppeng, Barru, Sinjai, Bulukumba and other cities or some districts in South Sulawesi. Bolu cukke is known for its high-calorie snacks because is composed of chicken eggs, wheat flour and brown sugar (Manjilala, Ekariskawati, \& Agustian, 2019). Bolu Cukke is made using molds with various shapes. The mixture of ingredients is inserted into the mold, then ripened by a baking. In the perception of local culture, bolu cukke is served in Anggaukeng as a part of Bugis wedding ceremonies (Ridha, 
Kadir, \& Sudirman, 2000). One of shapes matches the characteristics of the rotating object following the shape of the mold.

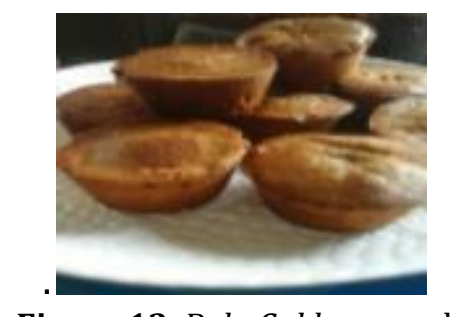

Figure 13. Bolu Cukke served

In mathematical tenet, the basic shape of the edge of bolu cukke can be described in a constant function $f(x)$ on the base, a linear function of $g(x)$ on the edge side and a quadratic function of $h(x)$ on the upper side. By using interpolation, three different functions are obtained as follows:

$$
\begin{array}{ll}
f(x)=1 & ; 0 \leq x \leq 2 \\
g(x)=3 x-5 & ; 2 \leq x \leq 3 \\
h(x)=-0.02 x^{2}+4.22 ; 0 \leq x \leq 3
\end{array}
$$

Furthermore, all functions are revolvable around the $y$-axis. Simulation of rotation of the function yieldsthe following form of bolu cukke.

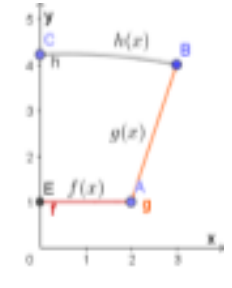

Figure 14. Linear and quadaratic function by interpolation

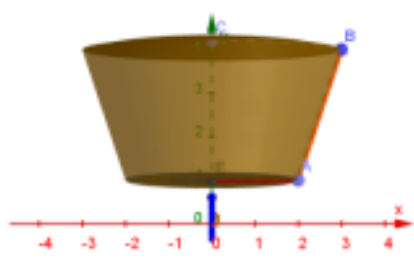

Figure 15. The simulation of linear and qauadratic function that are rotated around $y$-axis

The volume formula can be obtained using the disk method. Because it revolves around the $y$-axis, the functions and the boundaries are inverse into new functions and boundaries.

$$
V_{\text {bolucukke }}=\pi \int_{1}^{4}\left(\frac{x+5}{3}\right)^{2} d x+\pi \int_{4.04}^{4.22}\left(\frac{x-4.22}{-0.02}\right) d x
$$

Another traditional cake resembling the geometry characteristics of bolu cukke is cantik manis. The difference from the physical appearance between cantik manis cake and bolu cukke is in top surface. Cantik manis cake seems more evenly, so that in its depiction, it is quite necessary for one linear function with a certain boundary and rotates against the $y$ axis. The way to obtain function marking the edges of the cantik manis is the use of interpolation providing bounded linear function:

$$
f(x)=4.55 x-4.55 ;(1 \leq x \leq 1.66)
$$

Furthermore, the volume model is formulated using the disc method. The linear function is first reversed, and boundaries are adjusted, so that the integral model can be obtained as follows:

$$
V_{\text {CantikManis }}=\pi \int_{0}^{3}\left(\frac{x+4.55}{4.55}\right)^{2} d x
$$


The process of plotting, interpolation, and revolution of linear functions around the $y$ axis is visualized in the following figure:

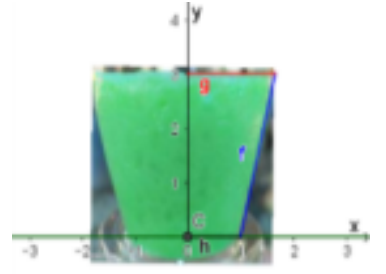

Figure 16. Plotting point at side edge of Cantik Manis

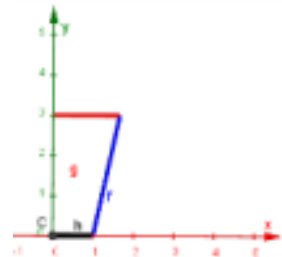

Figure 17. Linear and constant function by interpolation

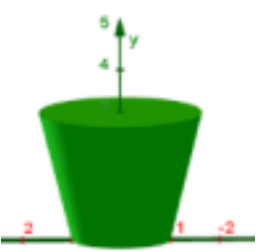

Figure 18. Revolution of linear and constant functions around y-axis

\section{$\mathrm{n}^{\text {th-Degree polynomial }}$}

\section{Putu cangkir}

Putu Cangkir is one of traditional cakes leading enhancement the economy of Buginese-Makassarese community. Based on the results of the interview, it can be explained that the processing technique starts with mixing white glutinous rice flour and sprinkling crushed brown sugar until evenly and it becomes a ready to mold dough. The dough is put in the middle of a bowl-shaped mold, then added grated young coconut and covered with rice flour dough. The next step is the dough with the coconut mixture in a steamed mold until being cooked. The explanation about ingredients and the processing putu cangkir is similar with the report on community empowerment in putu cangkir business development (Sahban, 2017).

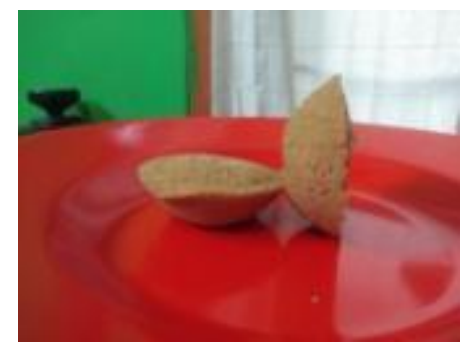

Figure 19. Putu Cangkir

The utilization of the bowl as a mold makes this cake resemble the characteristics of the solid object. the result of interpolation in GeoGebra obtains the side generating quadratic polynomial equation as shown in the equation as follows:

$$
f(x)=-0.33 x^{2}+2.84 x-3.14 ;(1.81 \leq x \leq 4)
$$

The polynomial square is revolved around the $x$-axis. The rotation of the function results in a rotating solid object with disc characteristics resembling putu cankir.

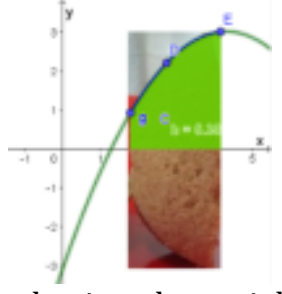

Figure 20. Quadratic polynomial as a result of interpolation

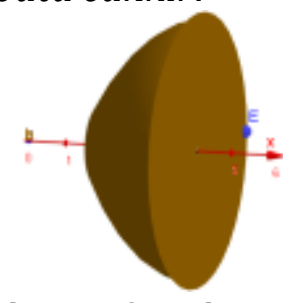

Figure 21. Simulation of quadratic polynomial thet is rotated around the $\mathrm{x}$-axis

Using the concept of the disk method, the volume model can be written in the following integral formula: 


\section{Barongko batara}

$$
V_{\text {PutuCangkir }}=\pi \int_{1.4}^{3.7}\left(-0.33 x^{2}+2.84 x-3.14\right)^{2} d x
$$

A variety of traditional corn-based foods should be preserved because they become a part of Nusantara's wealth. For Buginese and Makassarese people, they process the corn as the traditional food in someways. One of ways is pudding served in some types including barongko batara, bassang, barobbo, and marning. Barongko batara is the result of modification of corn dodol into pudding. It can further be processed to be corn barongko. In addition to corn, other ingredients used in making barongko batara are coconut milk, eggs, sugar, gelatin, vanilla and salt to taste. Corn pudding dough is made from a mixture of sliced corn that has been mashed with other ingredients. In the process, barongko batara is explored to find characteristics of revolution.

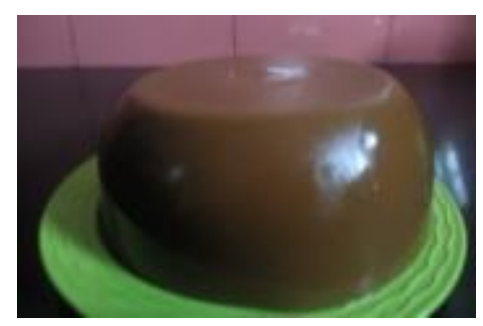

Figure 22. Barongko Batara

Geometrically, this corn pudding has different shapes following the shape of the dough mold. However, barongko batara has a shape appropriate with the characteristics of solid of revolution. Some images of corn pudding are presented. By fitting data, a quatric polynomial function is obtained as follows:

$$
g(x)=-0.007 x^{4}+0.53 x^{3}-1.59 x^{2}+2.15 x+1.3 . ; 1.4 \leq x \leq 3.7
$$

This quartic polynomial is rotated around the $x$-axis resulting in a rotating object

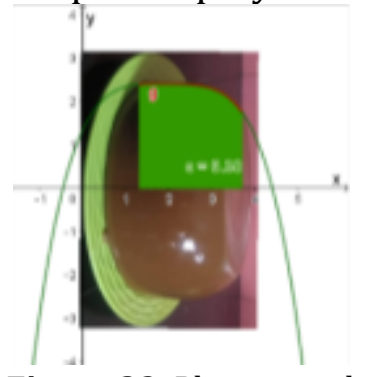

Figure 23. Plotting and interpolation on the side of barongko batara

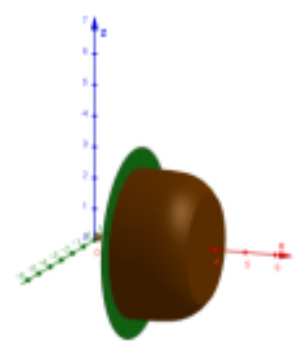

Figure 24. Revolution of quatric polynomial

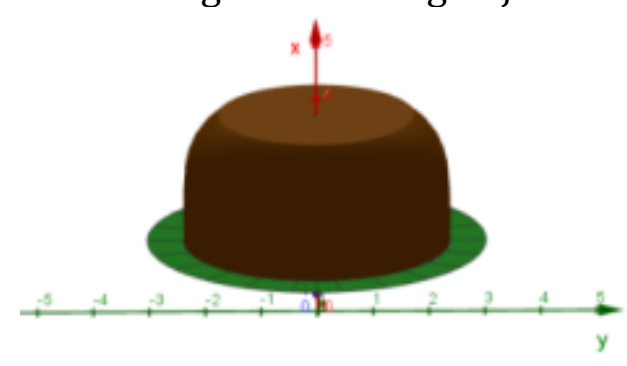

Figure 25. Rotating image to the horizontal view

The volume model formulated by disk method can be written as follows:

$$
V=\pi \int_{1.4}^{3.7}\left(-0.007 x^{4}+0.53 x^{3}-1.59 x^{2}+2.15 x+1.3\right)^{2} d x
$$

Barongko batara has various variants depending on the shape of the mold. One of variants is that there is a hole in the middle of the pudding. Moreover, it can also be explored by using a solid of revolution with the method of washers.

\section{Cuсuru}

Dumpi cucuru, or Dumpi eja in Konjo language, is one of highly sacred traditional foods. This cake should be served in various traditional ceremonies. For Kajang people in 
Bulukumba Regency particularly, dumpi eja must be dished out in Kalomba event. It is one of cultural heritages in the form of rituals conducted Kajang people, as a life cycle ceremony intended to ask for safety for children in order to avoid curses, and diseases (Raodah, $\underline{2020}$ ). As the result of the interview conducted with Ramlah, as a jannang or dumpi cucuru maker, she stated that:

"Dumpi cucuru is made from crab rice soaked for 10 hours and ground into fine flour, mixed with palm sugar that has been finely sliced and diluted. It is further added with water and stirred until evenly so that it becomes a dough. Next, the dough is put in boiling oil. In Kalomba activities, dumpi eja becomes a prayer for children in orderto look physically sweet, behave politely, and speak politely. Dumpi cucuru is also used as a ceremony in the wedding ceremony addressed to the groom to the bride. With a sweet taste, dumpi eja is also believed as a prayer to combinethe sweet feelings and bind the affection between the bride and groom".

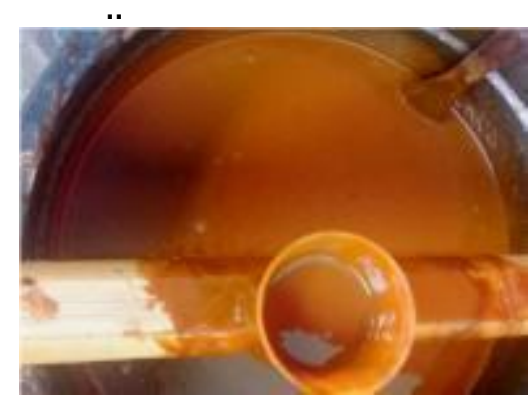

Figure 26.The dought of Cucuru

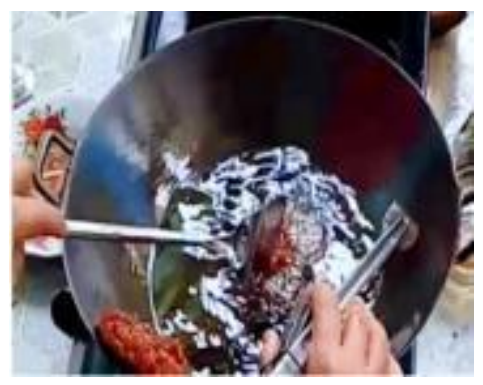

Figure 27. the process of frying

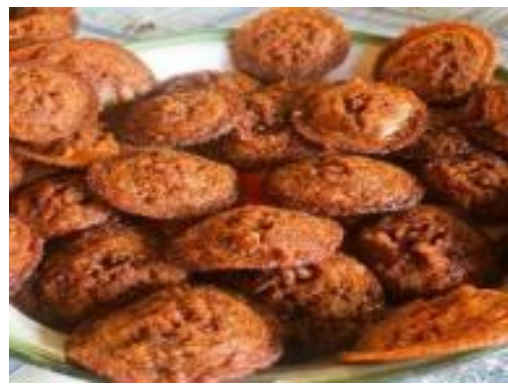

Figure 28. Dumpi Eja Source : https://www.tagar.id/dumpi-eja-kue-sakral-suku-kajang-bulukumba

In the concept of its geometry, cucuru dumpi is similar to the characteristics of irregular rotating objects. Its shape is irregular because the dough being put in the frying pan, form an uneven surface. However, it can still be approximated using interpolation methods. In the stage of data ploting and interpolation, the basic curve can beobtained in the form of nonic polynomial as follows:

$$
\begin{gathered}
p(x)=1.12 x^{9}-25.02 x^{8}+242.15 x^{7}-1335.23 x^{6}+4619.44 x^{5} \\
-10396,5 x^{4}+15223.62 x^{3}-13993.66 x^{2}+7336.11 x \\
-1671.96 ;(1 \leq x \leq 4)
\end{gathered}
$$

The result of simulating the revolution of the $p(x)$ function around the $x$-axis, can be visualized in figures:

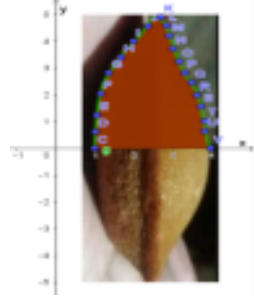

Figure 29. Plotting point and Interpolation at image of cucuru

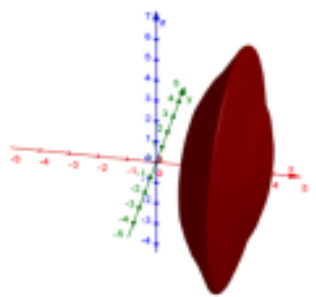

Figure 30. Simulation of revolution of nonic polynomial

Nevertheless, this cake can be found in Buginese or Makassares people, especially in some cultural activities. As in the previous type, the volume model of the spell dumpi can be written in integral formula:

$$
V=\pi \int_{1}^{4} p(x)^{2} d x
$$




\section{Solid of revolution : Washers method}

Bludere

Bludere is the type of bread categorized as a traditional cake. In Aggaukeng event held in wedding parties, bludere is in the type Indo Beppa cake. It is relatively large size and has been not sliced. It is stored in the Bosara and brought as a groom to the bride (Ridha et al., 2000). Based on the result of the interview with two informants, they said that:

"The main ingredients of this bludere cake are eggs, wheat flour, granulated sugar, brown sugar, and water coupled with a number of cake mixture ingredients such as TBM, vanily powder, milk, chocolate powder and additional walnuts. The ingredients are mixed and processed specifically so as to produce a soft texture."

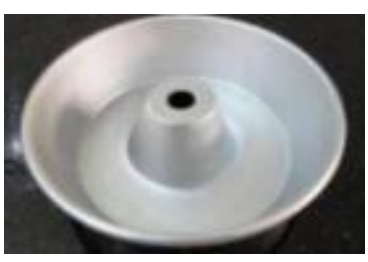

Figure 31. The mold of bludere

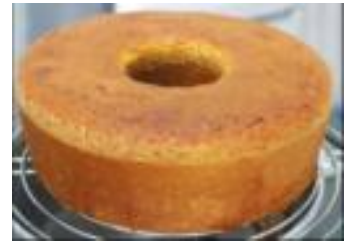

Figure 32. Bludere cake

Under geometry concept, the shape of bludere resembles the charactericic of a rotating solid object with a cavity in the middle. The bludere shape follows a cylindrical mold and has a border resembling a cone cut in the middle. Mathematical model obtained through interpolation techniques from the outer boundaries of bludere consists of four functions:

$$
\begin{aligned}
& f_{1}(x)=3 x-5 \\
& f_{2}(x)=-4.42 x+5.42 \\
& f_{3}(x)=1 \\
& f_{4}(x)=2.5
\end{aligned}
$$$$
; 2 \leq x \leq 2.5
$$$$
;(0.66 \leq \text { 牡 } \leq 1)
$$$$
;(1 \leq x \leq 2)
$$$$
\text { ; }(0.66 \leq x \leq 2.5)
$$

In the VOSR concept, bludere meets the characteristics of the washers method. The simulation of revolution of four functions revolves around the $y$-axis as shown figure 32 .

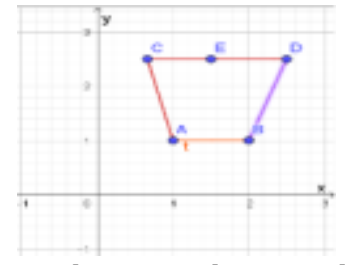

Figure 33. Ploting and interpolation at the edge of bludere

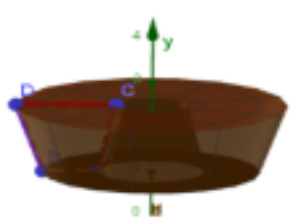

Figure 34. revolution of linear and constant function around $\mathrm{y}$-Axis

The volume model can be completed by an inverse the above functions along with the transformation of the boundaries.

$$
\begin{gathered}
V_{\text {outside }}=\pi \int_{1}^{2.5}\left(\frac{x+5}{3}\right)^{2} d x \\
V_{\text {cavity }}=\pi \int_{1}^{2.5}\left(\sqrt{\frac{x-5.42}{-4.42}}\right)^{2} d x
\end{gathered}
$$

As a result, volume model can be formulated by : $V_{\text {bludere }}=V_{\text {luar }}-V_{\text {rongga }}$ 


\section{Sarang semut}

$$
V_{\text {bludere }}=\pi \int_{1}^{2.5}\left(\frac{x+5}{3}\right)^{2}-\left(\sqrt{\frac{x-5.42}{-4.42}}\right)^{2} d x
$$

Sarang semut is also known as caramel sponge. It is not only famous in Buginese community, but it is also almost in all over Indonesia. This cake is included in the type of wet cake favored in various communities. Although the sarang semut is known as modern cake, it is also often found in various events such as in religious events, in family gatherings, or in cultural ceremonies. In the manufacturing process, palm sugar is melted into a dark brown liquid and water is then added. The melted brown sugar that has been recooled is mixed with the whipped butter, some eggs and also additional flour, bicarbonate, and baking powder. The whole of this mixture, becomes a dough. It is then ready to be put into the mold or baking pan. Through the baking process, it becomes an ant nest cake with a shape following the baking pan. Generally, the mold used is the same shape as the mold in making bluder cake, which is cylindrical in shape with a cavity in the middle.

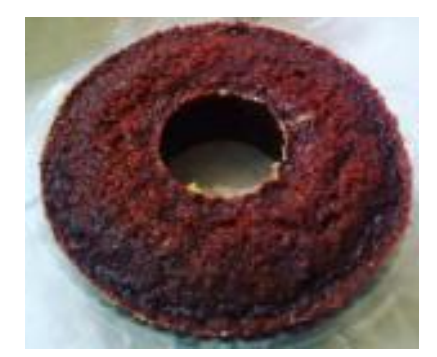

Figure 35. Bolu sarang semut

Based on the geometrical point of view, the shape of sarang semut is found similar to the characteristics of a solid of revolution with the basic shape of a curved plane. Through the implementation of interpolation, two algebraic equations are obtained including the quadratic equation for the outer side and the linear equation for the cavity side.

$$
\begin{gathered}
f_{\text {outside }}(x)=-1.73 x^{2}+5.96 x-2.68 ;(1.64 \leq x \leq 2.1) \\
f_{\text {cavity }}(x)=0.1 x+0.73 ;(1,64 \leq x \leq 2.1)
\end{gathered}
$$

The results of the rotation of the quadratic and linear equations about the $x$-axis can be figured as follows:

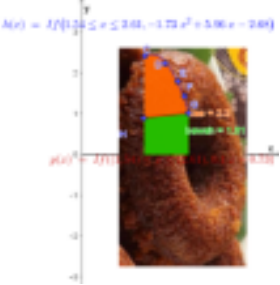

Figure 36. Plotting point and interpolation at image of sarang semut

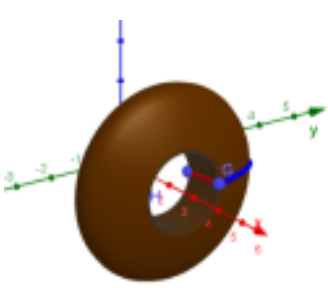

Figure 37. Revolution of two functions with washers method

The integral model for its volume uses the ring method (Varberg et al., 2006). The cake has a cavity or hole in the middle so that the volume model can be written as follows:

$$
V_{\text {SarangSemut }}=V_{\text {outside }}-V_{\text {cavity }}=\pi \int_{1.64}^{2.1}\left(f_{\text {outside }}\right)^{2}-\left(f_{\text {cavity }}\right)^{2} d x
$$


The volume of solid of revolution by shells method

Pisang ijo

Pisang ijo (Green Banana) is very popular as one of culinary snacks in the region of South Sulawesi. Pisang ijo has culturally become a popular culinary icon for the Buginese and Makassareses communities. Moreover, es pisang ijo is one of Makassar's local culinaries registered as intellectual property rights from Ministry of Tourism of the Republic of Indonesia (Perwira \& Haming, 2017). However, there are no accurate sources regarding the origin of pisang ijo, but the green color for Makassarese people in the aspect of food is assumedly sacred, and gives a cool and peaceful feeling.

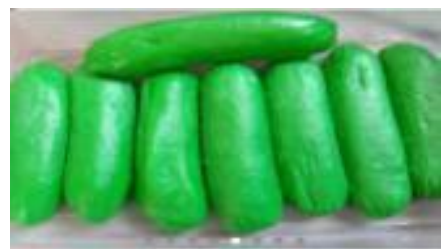

Figure 38. The shape of pisang ijo

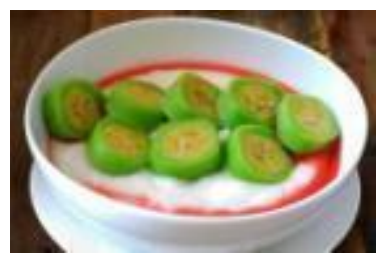

Figure 39. The slices of pisang ijo

Based on the basic shape of pisang ijo, the model of VOSR is found. The methods applied to find the model are the disk and the cylindrical shell methods. The shape of the banana as the basic material makes the pisang ijo align with the basic character of solid of revolution.

In this study, a set of points has been constructed in such a way as to represent the basic shape of omelette and banana layers. Furthermore, through the interpolation method, the following are two functions obtained:

$$
\begin{aligned}
& f_{\text {total }}(x)=-0,02 x^{4}+0.25 x^{3}-1.84 x^{2}+6.97 x-8.74 ;(2.27 \leq x \leq 19.46) \\
& \begin{aligned}
f_{\text {banana }}(x) & =0.01 x^{5}-0.02 x^{4}+2.56 x^{3}-19.38 x^{2}+75.88 x \\
& -118.37 ;(4.48 \leq x \leq 17.44)
\end{aligned}
\end{aligned}
$$

Two functions rotate about the $x$-axis using a surface with GeoGebra. The following are figures:

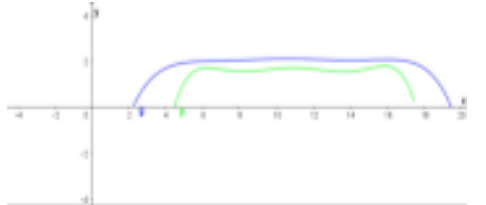

Figure 40. The representation function of pisang ijo

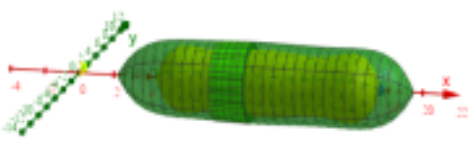

Figure 41. The rotation of two layers

The shape of bananas as a basic factor of solid rotation can be explored by disk method. Otherwise, omelette covered in bananas can be explored using the ring method approach, as the difference between the total volume and the volume of bananas is expressed in the following formula:

$$
\begin{gathered}
V_{\text {total }}=\pi \int_{2.27}^{19.46}\left(f_{\text {total }}\right)^{2} d x \\
V_{\text {banana }}=\pi \int_{4.48}^{17.74}\left(f_{\text {banana }}\right)^{2} d x \\
V_{\text {tepung }}=V_{\text {tot }}-V_{\text {pis }}
\end{gathered}
$$


Exploration and application of the cylindrical shell method can be viewed by taking a cylindrical piece of green banana. The physical model of the flour omelette covering the banana can be illustrated in the following figures:

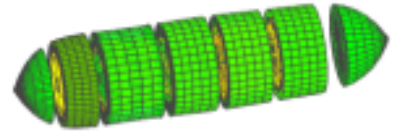

Figure 42. The pieces of pisang ijo

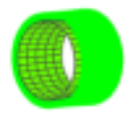

Figure 44. The layer of green omlete without banana

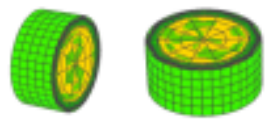

Figure 43. Visuaitation of a pieces of pisang ijo by horizontaly and vertically

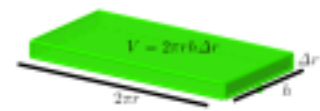

Figure 45. Overlaid omelette visualization

The integral model for determining the volume of flour omelet in the selected pieces can be represented by tube shell method.

$$
\begin{gathered}
\Delta V_{\text {pieces of omlete }}=2 \pi f(x) h\left(f_{\text {tot }}(x)-f_{\text {banana }}(x)\right) ; h=x_{i+1}-x_{i} \\
V_{\text {tepung }}=2 \pi \int_{x_{i}}^{x_{i+1}}\left(f_{\text {tot }}(x)-f_{\text {banana }}(x)\right) d x
\end{gathered}
$$

\section{Onde-onde}

Onde-onde has a basic shape like a ball, although it doesn't use a mold like in the previous descriptions of making cakes or food. In cultural perceptions, onde-onde for Buginese ethnic groups is a food served at special ceremonies, such as mappakulawi (aqiqah), mappano lopi (first boat drop off to sea), mappettuada' (engagement ceremoni), mappacci, mappenre bola beru or ambaung balla' (building house). It is similar with the results of interview conducted by Hapi' and Nurdeni in Bulukumba. It explains that the making of onde-onde don't use a mold, but by hands directly and rolling it. Onde-onde is a traditional cake made from glutinous rice flour and processed by boiling. In addition, the process of making onde-onde also requires brown sugar, white grated coconut, and clean boiled water. The small sphere is made by processing the shape using rolled and kneaded ways with the palm of the hand. This circle is flattened and given a piece of brown sugar in the form of a dice. Hereafter, the flour dough is rolled back using the palm of the hand so that the dough wraps around the sugar pieces. Further, the spheres are reboiled. After the process of boiling, the brown sugar inside is no longer in the form of diced, because it has been rounded and boiled so that it becomes thick. Because of using the basic ingredients of solid flour, palm sugar and coconut, onde-onde is believed to be able to give people a clear purpose and goodness (Nahriana \& Pangki, 2019).

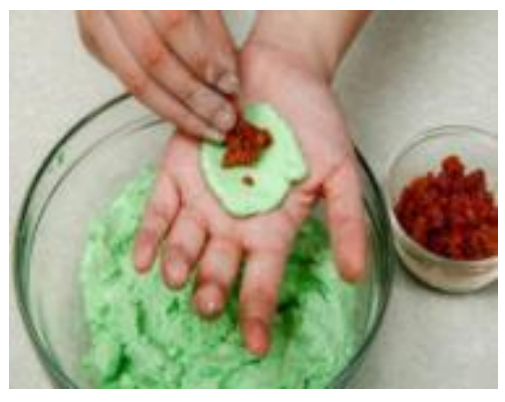

Figure 46. The Process of making Source: https://asianfoodnetwork.com

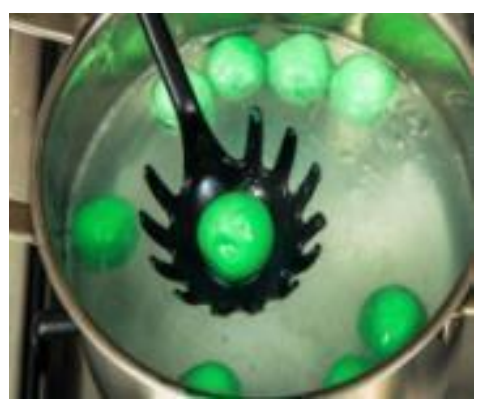

Figure 47. Boiling Proces

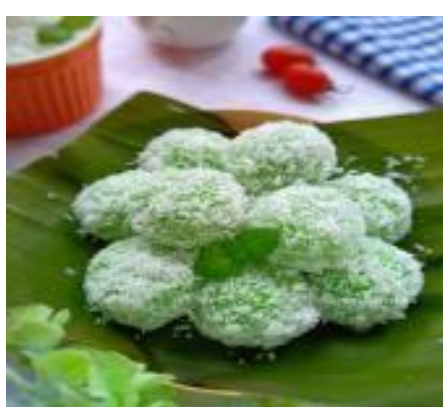

Figure 48. Onde-onde 
In previous studies, the geometry of onde-onde was investigated for obtaining the adjustment to the properties of spherical geometry (Huda, 2018; Pathuddin \& Raehana, $\underline{2019}$ ). In their study, mathematical aspects in onde-onde focus on modeling functions showing the outer shape. The resulting function is rotated through the $x$-axis. Furthermore, the volume model is made using two methods, namely the ring method and the spherical shell method made as the development of the shells method.

Furthermore, the shape of sugar after being boiled is assumed in the form of a sphere and follows the shape of cover, so that its volume is smaller than the volume of the flour that surrounds it. A mathematical model of onde-onde cake is distinguished from the blanket model with the brown sugar model in the middle.

The mathematical model is formulated without an interpolation technique. However, it is assumed that both cover of onde-onde and brown sugar are represented by parabolic equation, showing $f_{1}(x)$ for flour as a cover of onde-onde and also $f_{2}(x)$ for thick brown sugar. The following equation is:

$$
\begin{gathered}
f_{1}(x)=\sqrt{1-(\text { 生 }-1)^{2}} ; 0 \leq x \leq 10 \\
f_{2}(x)=\sqrt{0.75-(x-1)^{2}} ; 0 \leq x \leq 10
\end{gathered}
$$

According to the geometry computational using GeoGebra for simulating the revolution of two parabolic functions around the $x$-axis, the physical model of onde-onde is obtained as shown in the following figure:

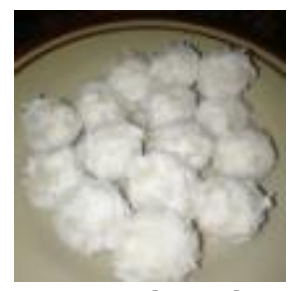

Figure 49. Onde-onde served

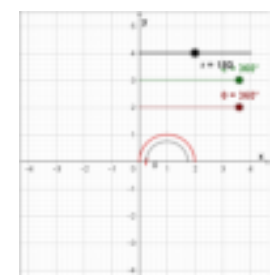

Figure 50. A couple of parabolic equation

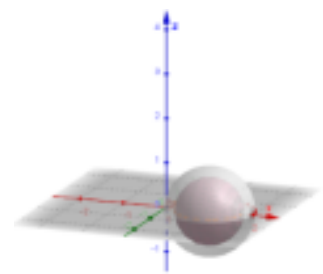

Figure 51. Revolution of two parabolic equations

Basically, the volume model of onde-onde can be written using $V_{\text {bola }}=\frac{4}{3} \pi r^{3}$ as the general spherical volume formula. However, the volume model is inthe integral approach of disk method. In the VOSR, the volume model of each layer can be written as follows:

$$
\begin{gathered}
V_{\text {palmsugarball }}=\pi \int_{a_{2}}^{b_{2}}\left(f_{2}(x)\right)^{2} d x \\
V_{\text {cover }}=\pi\left[\int_{a_{1}}^{b_{1}}\left(f_{1}(x)\right)^{2} d x-\int_{a_{2}}^{b_{2}}\left(f_{2}(x)\right)^{2} d x\right]
\end{gathered}
$$

Furthermore, the standard equation of the circle used can be shown that if the standard equation of the circle is reintegrated using the disk method, it will obtain the volume of a sphere in general as the following equation:

$$
\begin{gathered}
x^{2}+y^{2}=r^{2} \Leftrightarrow y=\sqrt{r^{2}-x^{2}} \\
V_{\text {onde-onde }}=\pi \int_{-r}^{r}\left(\sqrt{r^{2}-x^{2}}\right)^{2} d x==\frac{4}{3} \pi r^{3}
\end{gathered}
$$


The shells of sphere

In addition, the volume of sphere can also explored by calculating the volume of spherical shells at a certain thickness. In this study, each layer of the spherical skin can be opened and overlaid with a thickness $\Delta r$ and with an area of $L_{\text {selimut }}=4 \pi r^{2}$. Thus, the volume of each layer and the total can be written as follows :

$$
\begin{array}{r}
\Delta V=\text { Lselimut }_{i} \cdot \Delta r \\
V=\sum_{i=1}^{n} 4 \pi r^{2} \cdot \Delta r
\end{array}
$$

If the thickness of each layer is made thinner, the following integral model is obtained:

$$
V=\lim _{\Delta r \rightarrow 0} \sum_{i=1}^{n} 4 \pi r^{2} \cdot \Delta r=\int_{0}^{r} 4 \pi r^{2} d r=\frac{4}{3} \pi r^{3}
$$

Buginese and Makassarese traditional foods as a contextual learning media

This research is only focused on mathematical modeling of the physical shape of traditional foods using the concept of interpolation for polynomial models and integrals for volume models. The results of this exploration have not been implemented in mathematics learning based on local culture. However, contextual learning can be designed by demonstrating the process of plotting points, generating polynomials, and visualizing a solid of revolution. Through contextual learning, students acquire a learning process involving cultural attributes. It can provide a comprehensive understanding for students (Pathuddin et al., 2021). Based on this research, exercises and problems can be developed as contextual learning for college students by using Buginese local food as a medium and GeoGebra as a tool.

\section{Concept of interpolation}

Contextual learning can be implemented on the topic of Interpolation. Technically, precise images are taken on contextual objects and then processed in the GeoGebra application. GeoGebra interpolation is functioned by plotting the boundary points, and generating the equation using the fitpolynomial command. For example, the assignment instructions to students can be shown in the following assignment instructions:

1. Find the some cakes that match the characteristics of solid of revolution

2. Create a polynomial model on this cake using the concept of interpolation on GeoGebra!

\section{Concept of volume of solid of revolution}

Based on the result of polynomial functions, it can be simulated in a rotating object through the rotation process of the generated function. This experiment can be explored with the aid of GeoGebra so that in the learning process of the Integral application, students can be given assignments to explore VOSR. The assignment given can be designed through the following instructions:

1. Simulate the polynomial into a solid of revolution object implemented in GeoGebra!

2. Determine the integration model that represents the volume of the selected cake!

3. Solve the definite integral model by using the basic rules for integrating polynomial!

\section{Conclusion}

The finding of this research mathematically discloses the application of the concept of interpolation and simulation of rotating objects by GeoGebra is very powerful in modeling polynomial functions and VOSR on the shape of Buginese and Makassarese traditional 
foods. The application of interpolation with GeoGebra shows that the basic shape equation can be represented by a constant function, a degree- 1 polynomial, a degree- 2 polynomial, or a degree- $n$ polynomial. Furthermore, in the simulation of rotating solid objects, they are classified into rotation about the $x$-axis, the $y$-axis, and the straight-line axis by linear equations. Certainly, the direction of rotation of each function affects the shapes and the volume model with the integral model. In addition to the direction of rotation, the volume model also depends on the method used, and the selection of method depends on the geometric characteristics. In this case, they are categorized in the slab, disk, washer, and cylinder shell method groups. Finally, the volume model of each type of food is represented in definite integral relying on the boundary, polynomial models, direction of rotation and four types of methods in the volume of solid.

Buginese and Makassarese traditional foods are unique in the perspective both culture, and education. Culturally, these traditional foods can be categorized as a part of food group served in religious events, traditional wedding ceremonies, or culinary snacks. Based on the discussion, this research finds that the geometric shape of each type of cake, is influenced by the shape of molds, the ingredients and directlyby hand.

The findings of this research are expected to be a source of mathematics learning for students. The diversity of shape of traditional food conforming with the characteristics of solid of revolution are also expected to help students understand the distinction of concept of slabs, disks, washers and shells. This research can be also used as a basis in developing further research such as in exploring the effectiveness of using these media in building students' creative and critical thinking skills.

\section{Acknowledgment}

A deep thank you to Dr. Buhaerah as Head of Mathematics Education Department and Dr. Saepudin as Dean of Tarbiyah Faculty for the moral support. Hopefully in the future the authors will be more productive and creative to contribute actively to the institution and advancement of education.

\section{Bibliography}

Abdullah, A. S. (2017). Ethnomathematics in Perspective of Sundanese Culture. Journal on Mathematics Education, 8(1), 1-16. https://doi.org/10.22342/jme.8.1.3877.1-16

Bittinger, M. L., Ellenbogen, D. J., \& Surgent, S. A. (2012). Calculus And Its Applications (D. Lynch, J. Crum, R. S. Reeve, \& J. Wendelken (eds.); Tenth). Pearsons Educations, Inc.

Cheney, E. W., \& Kincaid, D. R. (2012). Numerical mathematics and computing. Cengage Learning.

Cooper, T. E. (2017). Function Fitting to Develop Class Projects: Alcohol Awareness Models in College Algebra. North American GeoGebra Journal, 6(1).

D'Ambrosio, U. (1985). Ethnomathematics and its Place in the History and Pedagogy of Mathematics. For the Learning of Mathematics - An International Journal of Mathematics Education, 5(1), 44-48.

D'Ambrosio, U. (1990). The role of mathematics education in building a democratic and just society. For the Learning of Mathematics, 10(3), 20-23.

Ezeife, A. N. (2002). Mathematics and culture Nexus: The interactions of culture and mathematics in an aboriginal classroom. International Education Journal, 3(3), 176187.

Hall, J., \& Lingefjard, T. (2017). Mathematical Modeling: Applications with GeoGebra. Canada. 
Herawaty, D., Widada, W., Novita, T., Waroka, L., \& Lubis, A. (2018). Students' metacognition on mathematical problem solving through ethnomathematics in Rejang Lebong, Indonesia. Journal of Physics: Conference Series, 1088(1), 12089. https://doi.org/10.1088/1742-6596/1088/1/012089

Hohenwarter, M., \& Fuchs, K. (2004). Combination of dynamic geometry, algebra and calculus in the software system GeoGebra. Computer Algebra Systems and Dynamic Geometry Systems in Mathematics Teaching Conference, 1-6.

Hohenwarter, M., \& Hohenwarter, M. (2002). GeoGebra. Retrived from http://www.Geogebra.org/cms/en.

Huda, N. T. (2018). Etnomatematika Pada Bentuk Jajanan Pasar di Daerah Istimewa Yogyakarta. Jurnal Nasional Pendidikan Matematika, 2(2), 217-232. https://doi.org/10.33603/inpm.v2i2.870

Kusumaningrum, B., Irfan, M., \& Agustito, D. (2019). Spatial ability of student in construct volume of the solid of revolution graphic Spatial ability of student in construct volume of the solid of revolution graphic. https://doi.org/10.1088/1742-6596/1315/1/012032

Manjilala, Ekariskawati, \& Agustian, I. (2019). Daya terima bolu cukke substitusi tepung kulit pisang dan tepung tempe pada balita gizi kurang. Media Gizi Pangan, 26(1), $71-$ 77.

Mofolo-mbokane, B., Engelbrecht, J., \& Harding, A. (2013). Learning difficulties with solids of revolution: Classroom observations International Journal of Mathematical Learning difficulties with solids of revolution : classroom observations. International Journal of Mathematical Education in Science and Technology, 44(7), 1065-1080. https://doi.org/10.1080/0020739X.2013.823253

Nahriana, \& Pangki, S. A. (2019). Inventarisasi dan Standarisasi Resep Kue Tradisional Makassar Berbahan Dasar Tepung Beras. Prosiding Seminar Nasional LP2M UNM 2019 "Peran Penelitian Dalam Menunjang Percepatan Pembangunan Di Indonesia," 477-481.

Nur, A. S., Waluya, S. B., Rochmad, R., \& Wardono, W. (2020). Contextual learning with Ethnomathematics in enhancing the problem solving based on thinking levels. JRAMathEdu (Journal of Research and Advances in Mathematics Education), 5(3), 331344. https://doi.org/10.23917/iramathedu.v5i3.11679

Orey, D. C., \& Rosa, M. (2007). Cultural Assertions and Challenges Towards Pedagogical Action. For the Learning of Mathematics, 27(1), 10-16.

Ozdemir, C., \& Cataloglu, E. (2014). The Development of An Inquiry Based Learning Unit for Integral Calculus: The Case of Volumes of Solids of Revolution. The Eurasia Proceedings of Educational \& Social Sciences, 1(1938), 117-123.

Pathuddin, H., Kamariah, \& Nawawi, M. I. (2021). Buginese Ethnomathematics : Barongko Cake Explorations as Mathematics Learning Resources. Journal on Mathematics Education, 12(2), 295-312. https://doi.org/10.22342/ime.12.2.12695.295-312

Pathuddin, H., \& Raehana, S. (2019). Etnomatematika: Makanan Tradisional Bugis sebagai Sumber Belajar Matematika. MaPan: Jurnal Matematika Dan Pembelajaran, 7(2), 307328. https://doi.org/10.24252/mapan.2019v7n2a10

Perwira, I., \& Haming, M. (2017). The Effect of Information Technology and Innovation on the Quality of Human Resources and Business Performance (An Exploratory Study of Typical and Traditional Culinary Typical of Makassar Famous ). 5-12. https://doi.org/10.9790/1813-0609030512

Raodah. (2020). Perkawinan dan Pelanggaran Adat di Komunitas Kajang, Kabupaten Bulukuba. Walasuji, 11(2), 217-234.

Ridha, M., Kadir, Y. A., Sudirman, H. ., \& dkk. (2000). Makanan, Kebudayaan dan Kesehatan 
pada Etnis Bugis di Kab. Bone, Sulawesi Selatan. Menyongsong Otonomi Daerah: Pemberdayaan Kembali Pranata Lokal, 385-398.

Rosa, M., \& Orey, D. C. (2011). Ethnomathematics : the cultural aspects of mathematics Etnomatemática: os aspectos culturais da matemática. Revista Latinoamericana de Etnnomatematica, 4(2), 32-54.

Sahban, H. (2017). Pengembangan Inovasi Kue Tradisional Putucangkir dalam Penguatan Ekonomi Masyarakat di Kabupaten Gowa. Digitalisasi Dan Transformasi Hasil Riset Dan Pengabdian Kepada Masyarakat Menuju Pengembangan Berkelanjutan, November.

Sihombing, S. C., Marmaini, \& Dahlia, A. (2020). Interpolasi Polinom Newton untuk Mengestimasi Fungsi Polinomial dari Suatu Benda Putar. Jurnal Penelitian Fisika Dan Terapannya (JUPITER), 2(1), 33-38. https://doi.org/10.31851/jupiter.v1i2.4994

Tasman, F., Padang, U. N., \& Ahmad, D. (2018). Visualizing Volume to Help Students Understand the Disk Method on Calculus Integral Course Visualizing Volume to Help Students Understand the Disk Method on Calculus Integral Course. April. https://doi.org/10.1088/1757-899X/335/1/012112

Varberg, D., Purcell, E. J., \& Rigdon, S. (2006). Calculus, 9th Edition. Prentice Hall, Inc.

Wahyudi, B. A., Octavia, F. A., Hadipraja, M., Isnaeniah, S., \& Viriani, V. (2017). Lemang (Rice bamboo) as a representative of typical Malay food in Indonesia. Journal of Ethnic Foods, 4(1), 3-7. https://doi.org/10.1016/j.jef.2017.02.006 